\title{
STUDENTS' NEEDS TO DEVELOP ENGLISH WRITING MATERIALS
}

\author{
Dedi Sumarsono'; Abdul Kadir Bagis ${ }^{2}$; Moh. Arsyad Arrafii ${ }^{3}$ \\ 1,2,3Faculty of Education for Language and Arts, IKIP Mataram \\ Jl. Pemuda No.59A, Mataram 83125, Indonesia \\ 1dedi_aqi1@yahoo.com, ${ }^{2}$ bages2013@gmail.com, ${ }^{3}$ moh_arrafii@yahoo.com
}

Received: $12^{\text {th }}$ July 2016/ Revised: $18^{\text {th }}$ November 2016/ Accepted: $31^{\text {st }}$ March 2017

\begin{abstract}
How to Cite: Sumarsono, D., Bagis, A. K., \& Arrafii, M. A. (2017). Students' Needs to Develop English Writing Materials. Lingua Cultura, 11(2), 67-71. http://dx.doi.org/10.21512/lc.v11i2.1504
\end{abstract}

\begin{abstract}
This research explored sophomore students'needs in learning English writing at the Faculty of Education for Language and Arts, IKIP Mataram. To achieve this purpose, classroom observation, questionnaire, and documentation were conducted to collect data. Data were then analyzed descriptively, and triangulation of data analysis was carried out. Based on the result of the questionnaire survey, the findings show that the students' proficiency level is at the elementary level. Moreover, the students'needs in learning writing include picture-enriched materials, academic writing, tourism-related topics, cooperative learning in use, and theories-driven writing materials. The findings are used as foundation knowledge to develop writing materials for students.
\end{abstract}

Keywords: need-based analysis, writing material, English writing materials

\section{INTRODUCTION}

Teaching material is one of the most important aspects of teaching and learning. Good teaching material is informative (informs the learner about the target language), instructional (guides the learner in practicing the language), experiential (provides the learner with experience of the language in use), eliciting (encourages the learner to use the language), and exploratory (helps the learner to make discoveries about the language). As different learners learn in different ways, the ideal materials aim to provide the learners with all these ways of acquiring a language. However, the reality is that the most commercially produced materials focus only on informing their users about language features and guiding them to practice them. Richards (2001) has commented that instructional materials generally serve as the basis of much of the language input that learners receive and the language practice that occurs in the classroom. For this reason, in order to achieve the intended characteristics, teaching materials should be well developed by considering the context and the needs of the users.

Materials development refers to all the processes that are done by practitioners who produce and/or use materials for language learning, including materials evaluation, the adaptation design, production, exploitation, and research. Ideally, all of these processes should be considered and should be related to produce language-learning materials. In the context of English language teaching in higher education, these processes seem to be neglected. Based on the researcher's observation of writing English materials taught at the Faculty of Education for Language and Arts (FPBS) IKIP Mataram, teaching materials used are sometimes inappropriate for the students' needs and context. The materials are sometimes not authentic and not relevant to the students' needs although they have already been written based on the curriculum syllabus. Besides that, the levels of English writing materials are not suitable for learners. Very often, the materials are too easy for a particular group of students, while others are too difficult. This condition causes students to get bored of studying and discourages them from following the lesson because they are confused about what they are studying and why they are studying the materials. In addition, in the classroom, students sometimes prefer doing other activities instead of listening to their lecturers during the teaching and learning process. For example, they talk to their friend, sit in the back row and constantly on their mobile phone, remind the lecturers that the time is over, come late with many excuses, etc. Moreover, many students take the course just because they want to get the score as the requirement for graduation and not because the materials or subjects are important to them. Only a handful of engaging and interesting materials based on students' needs have been developed, especially in the context of FPBS IKIP Mataram.

Dealing with the explanation above, student needbased writing materials need to be developed in order to meet the needs for both lecturers and students. Need-based materials can further attract the students' motivation and 
interest to study. Therefore, this research intends to identify the needs of students of FPBS IKIP Mataram on English writing material.

In the process of designing teaching materials, many suggestions are offered on the factors that shape a good set of writing materials. Among them are to look at (1) topics or specialization, (2) learners' situation, (3) general and specific proficiency of the language at entry and exit levels, (4) students' previous educational, and (5) cultural experience. The developers should also look at types of skills to be developed and expected outcomes of the learning goals. The current trend shows that many authors in the field of English teaching are trying to make their materials as interesting and as accessible as possible. Tomlinson (2008) has described positive trends in materials development as those that lead to self-discovering the language, using corpuses for their development, using extensive reading, personalizing the process and experience, and speaking grammar in use.

While developing materials, developers should not forget the aspects of linguistic that are important and well connected in writing features such as lexical items. There is also need to remember that language forms topics for conversations while trying to integrate all the four skills in English with authentic texts. Authentic materials and language teaching can never be separated. Students or learners should be provided with authentic materials that reflect their real world. Materials used should be able to link and relate to the students' background knowledge as well as their language ability.

The main concern is the issue of language and content focus, drawn from the input in order to fulfill any tasks given to them (Hutchinson \& Waters, 1987). Materials should benefit students for when they go out to the real world. It should help them to not only function well in the real world but also use English in their working life. Harding (2007) has suggested three recommendations to consider while coming up with a set of materials (1) using context, texts, and situations from the students' subject area - whether they are real or stimulated - will naturally involve the language that students need, (2) exploiting authentic materials that students use in their specialism or vocation, and (3) making the tasks authentic.

One of the most important things in developing teaching materials is the analysis of students' needs toward their learning materials. Needs analysis is a process of collecting and analyzing information about learners in order to set goals and contents of a language curriculum, based on their needs (Kayl, 2008). It examines what learners already know and what they need to know (Nation \& Macalister, 2010). Many scholars indicate that knowing about learners' needs such as their learning objectives, language attitudes, and expectations from the course are necessary in order to design an efficient curriculum (Kayl, 2008). By gathering such information, the needs analysis can guarantee that the course will contain relevant and useful things for the students to learn.

There is a wide range of information that can be gathered in needs analysis. According to Hutchinson \& Waters, as cited in Nation \& Macalister (2010), needs are divided into target needs and learning needs. They have suggested that the information of target needs can be analyzed by looking at necessities, lacks, and wants. Besides that, they also make another major division to collect the data of needs. There are present knowledge and required knowledge as well as objective needs and subjective needs. Hence, they roughly make pairings that fit lacks into present knowledge, necessities into required knowledge, and wants into subjective needs (Nation \& Macalister, 2010).

According to Dudley-Evans \& St John (2011), needs analysis holds some aspects that include target analysis, present situation analysis, and learning needs analysis. The present situation analysis deals with the identification of learners' weaknesses or lacks (Petrova, 2008). Meanwhile, the target and learning needs are also known as the objective needs and the subjective needs (Petrova, 2008; Nation \& Macalister, 2010). The analysis of target or objective needs looks into the requirements of the language used in the contexts where the course participants are likely to use English. The learning or subjective needs analysis examines the learners' perceptions of what the course should be like. In other words, the analysis of objective needs should reveal the language skills or the language focus that should be developed more for the learners to be able to cope with the target situation in the future. In addition, such learning styles and expectations of learners cannot be ignored in the organization of courses as they might foster their learning.

Other information that is necessarily identified is about students' necessities, lacks, and wants. Firstly, necessities deal with what the learner has to know in order to function effectively in the target situation (Kaewpet, 2009). Like the illustration, if the purpose of the course is to prepare students to enter university, the needs analyst should analyze the style of language needed for assignments or to be used in everyday class. Information about the language element that is mostly demanded can be gathered through the interview with the university students who are considered to have had enough experience with the target situation.

Secondly, according to Nation and Macalister (2010), lacks analysis involves looking at where the learners are currently. It can comprise of the learners' strengths and weaknesses on the target language. There are several ways of gathering this information, they are (1) looking at the documents of students' previous learning product, (2) interviewing the teacher who is responsible for giving marks or grades, (3) interviewing the students on how they perceive the assignment and how they deal with it, and (4) providing test that measures the language proficiency of students.

Lastly, Nation and Macalister (2010) have also described wants as what the learners view about what they need and what they think is useful for them. Regarding this element, Berwick and Brindley, as cited in Kaewpet (2009), has stated that the learners' needs of English depend on various expectations, interpretations, and individual value judgments. On the other hand, Vandermeeren, as cited in Kaewpet (2009), has pointed out that the researchers or the needs analysts also have attitudes concerning language needs. This inevitably influences their choice of objectives and interpretation of the findings. Since this type of information is subjective, it should be seen whether the learners' views and the analyst's views are the same or not. It is therefore important to ensure that the interpretation is taken from various perspectives, which might consist of the learners, teachers, and institutions.

There are some tools for collecting the information in this needs analysis. Nation and Macalister (2010) have said that information about objective needs can be gathered by questionnaires, personal interviews, documentation, observation, tests as well as informal consultation with teachers and learners. Subjective needs are discovered through learners' self-assessment using lists, scales, questionnaires, and interviews. As the example, some of 
the tools are employed by Kayl (2008) in his case study on Developing an ESL Curriculum Based on Needs and Situation Analysis. In order to collect the data, he/ she observed students in an adult ESL program, gave students questionnaires to determine their needs, and then interviewed the teacher with the same purpose.

Kaewpet (2009) has further claimed that learner needs should be analyzed on an ongoing basis because they are likely to change over time, depending on contextual and human affective variables. Similarly, Nation and Macalister (2010) have also said that the times of needs analysis can include needs analysis before the beginning of a course, in the initial stages of a course, and during the running of the course. Petrova (2008) has added that the needs analysis should be conducted before the beginning of a course if nothing is known about the target learners. On the other hand, if the purpose of needs analysis is to evaluate and revise the program, it is reasonable to conduct it when the course is over. Thus, the needs analysis can be carried out in a particular period of time, depending on its purposes.

\section{METHODS}

This research and development on English writing material are based on the students' needs with 100 students involved. To achieve the purpose, some methods of data collecting were involved, which included interviews, classroom observation, questionnaire, and document analysis. Classroom observation was conducted to obtain information about the current practice of teaching and learning in the classroom. Through observing classroom teaching and learning, observers could identify whether the materials suit students' needs. Interview with students and questionnaire have the purpose of exploring students' opinions about the current English materials used in the classroom and to discover students' needs in relation to English materials. Document analysis was used to gather information about the relevance of textbooks and materials used in the classroom with students' needs. For data analysis, the inductive thematic analysis was used to analyze the qualitative data from interview and the data from the questionnaire, which would be used to triangulate the data from the interview. Descriptive analysis differentiates textbooks/materials which meet students' needs from those that do not.

English handouts have been constructed based on the information of students' needs obtained. Once the draft of the handouts was completed, focus group discussion (FGD) with students and teachers was conducted to obtain deeper information about student-based English materials. The research, however, focuses on reporting students' writing needs obtained from the questionnaire, which was distributed to 100 second-year students at FPBS IKIP Mataram.

\section{RESULTS AND DISCUSSIONS}

In order to comprehend the students' needs in learning writing, the survey questionnaire was distributed to 100 students as the respondents of the study. The questionnaire results in three key findings, which are the description of learning targets, students' proficiency level, and students' learning needs.

Target needs refer to what the learners need to know in order to function in the target situation as well as what they already know, and what they want to know. The target needs analysis includes the goal and the students' proficiency level. The data in Table 1 shows the percentages of the writing sub-skills already mastered, Table 2 shows the description of what students want to be improved, Table 3 shows the description of writing strategy of students, and Table 4 shows the writing strategy needs to be improved by the students.

Table 1 The Description of Writing Sub-Skills Mastered by Students (in Proportion)

\begin{tabular}{clcc}
\hline \multirow{2}{*}{ No } & \multicolumn{1}{c}{ Writing Sub-Skills } & \multicolumn{2}{c}{ Level } \\
\cline { 3 - 5 } & & Yes & No \\
\hline 1 & $\begin{array}{l}\text { Using appropriate vocabulary in writing } \\
\text { sentence }\end{array}$ & 41 & 59 \\
2 & $\begin{array}{l}\text { Using appropriate vocabulary in writing } \\
\text { paragraph }\end{array}$ & 13 & 87 \\
3 & Using appropriate vocabulary in writing & 11 & 96 \\
& essay & & \\
4 & Using good grammar in writing sentence \\
5 & Using good grammar in writing paragraph & 7 & 93 \\
6 & Using good grammar in writing essay & 8 & 95 \\
7 & Using good punctuation in writing sentence & 10 & 90 \\
8 & Using good punctuation in writing paragraph & 9 & 91 \\
9 & Using good punctuation in writing essay & 6 & 94 \\
10 & Using good generic structure in writing & 0 & 100 \\
& sentence & & \\
11 & Using good generic structure in writing & 0 & 100 \\
& paragraph \\
12 & Using good generic structure in essay & 0 & 100 \\
13 & Using cohesive device in writing paragraph & 6 & 84 \\
\hline
\end{tabular}

Table 2 The Description of Writing Sub-Skills that the Students Want to Improve (in Proportion)

\begin{tabular}{clcc}
\hline \multirow{2}{*}{ No } & \multicolumn{1}{c}{ Writing Sub-Skills } & \multicolumn{2}{c}{ Need } \\
Improvement
\end{tabular}


Table 3 The Description of Writing Strategy Mastery

\begin{tabular}{llll}
\hline \multirow{2}{*}{ No } & \multicolumn{1}{c}{ Writing Strategies } & \multicolumn{2}{c}{$\begin{array}{c}\text { Mastery } \\
\text { Level }\end{array}$} \\
\cline { 3 - 4 } & & Yes & No \\
\hline 1 & Converting numbers into writings & 65 & 35 \\
2 & Writing based on the picture available & 16 & 91 \\
3 & $\begin{array}{l}\text { Writing sentence or paragraph using good } \\
\text { grammar }\end{array}$ & 16 & 84 \\
4 & Arranging words or sentences & 39 & 61 \\
5 & $\begin{array}{l}\text { Writing by answering or completing the } \\
\text { questions given }\end{array}$ & 60 & 40 \\
6 & $\begin{array}{l}\text { Writing by giving conclusion with their } \\
\text { own words }\end{array}$ & 44 & 54 \\
7 & $\begin{array}{l}\text { Writing by answering the questions based } \\
\text { on the material given }\end{array}$ & 60 & 40 \\
\hline
\end{tabular}

Table 4 The Description of Writing Strategy Mastery that the Students Want to Improve

\begin{tabular}{llcc}
\hline \multirow{2}{*}{ No } & \multicolumn{1}{c}{ Writing Strategies } & \multicolumn{2}{c}{$\begin{array}{c}\text { Need } \\
\text { Improvement }\end{array}$} \\
\cline { 3 - 4 } & & Yes & No \\
\hline 1 & Converting numbers into writings & 82 & 18 \\
2 & Writing based on the picture available & 85 & 15 \\
3 & $\begin{array}{l}\text { Writing sentence or paragraph using } \\
\text { good grammar }\end{array}$ & 89 & 11 \\
4 & $\begin{array}{l}\text { Arranging words or sentences } \\
5\end{array}$ & 89 & 11 \\
& $\begin{array}{l}\text { Writing by answering or completing the } \\
6\end{array}$ & 93 & 7 \\
& $\begin{array}{l}\text { Writing by giving conclusion with their } \\
\text { own words }\end{array}$ & 86 & 14 \\
7 & $\begin{array}{l}\text { Writing by answering the questions } \\
\text { based on the material given }\end{array}$ & 89 & 11 \\
\hline
\end{tabular}

Another finding regarding the target need is the students' proficiency in writing. The proficiency level of the students in writing is mostly in elementary. Specifically, there are 81 students whose proficiency is in elementary, 18 students are in intermediate, and one student are in advanced level. Another interesting finding is their learning needs. Learning needs refer to what the learners need to do in order to learn. It concerns the methods and activities in the learning process. This phase presents the material, genre of writing, length of writing, topics, theories of writing, the activity in learning, the assessment, duration in writing the paragraph, and technique used by the lecturer.

The findings further show that the students have six necessities in learning writing. They are (1) material or topic presented using step-by-step instruction $(53 \%$ of the students), (2) academic writing as the topic (78\% of the students), (3) tourism topic to be discussed in learning writing (65\% of the students), 4) learning writing by working in group activities (60\% of the students), (5) theories about writing before starting to write (100\% of the students), and (6) assessment by the lecturers ( $91 \%$ of the students).

The writing proficiency of most students at the second semester is elementary level. That level, according to Brown (2004), is where students are able to produce appropriate vocabulary within a context, collocation, idioms, and correct grammatical features up to the length of sentence.
It is rather an awkward finding since students in Indonesia learn English as a compulsory subject since secondary school. Considering the length of learning English, it is not excessive to expect that the second semester of English department students should have the higher level of English proficiency. Unfortunately, due to the lack of placement test to group students according to their proficiency level after recruitment, the writing ability of students' in a classroom still varies.

The findings continue to show what materials students are interested in for learning. They are materials which use the picture as media and picture-cued task as a strategy for writing tasks. It makes sense as they have been guided by simple and easy media to enable them to finish writing tasks since they were in elementary levels. Many types of research provide evidence of the beneficial effect of using pictures as media for writing task since it piques students' interest and makes learning fun. Brown (2004) has said that the main advantage of this technique is to detach the almost ubiquitous reading and writing connection and instead offer a non-verbal means to stimulate written the response.

Regarding the genre of writing, most of the students prefer academic writing to be discussed. It is not surprising because the students will always deal with the academic situation such as writing essay, paper, thesis, etc. In line with this, as part of academic literacy, instructors not only need to develop students' academic writing but also to prepare them for externally mandated large-scale document critical evaluation, including online documents. The rationale of peer assessment of academic writing is, providing the learner opportunities to develop tacit knowledge rather than explicit knowledge about the meaning of the core criteria. It is also important to learn how they are applied rather than focusing on internalization of explicit rules or standards for academic writing (Elander, Harrington, Norton, Robinson, \& Reddy in Defazio et al., 2010).

The next finding is that most of the students are interested in topics related to tourism. It has been anticipated that students will select the tourism topic as a major topic for their writing tasks. This phenomenon relates to the fact that Lombok is a tourism island which is visited by many local and international tourists. Tourism is a part of the lives of people in Lombok.

In addition, studying in groups is also one of the findings regarding the students' need in learning writing. It is reasonable for the students because by learning together with their friends, they can collaboratively solve the problems they face. As Knight \& Bohlmeyer in Gillies \& Ashman (2003) have argued that the research has only demonstrated that co-operative learning experience causes variance in many of these proposed mediating variables. However, it is not established that these variables are the mechanisms through which co-operative learning influenced the achievement. Clarification within this debate is important because it will enable researchers to predict how and under what circumstances does co-operative learning influence academic achievement. Furthermore, Kuo, Chu \& Huang (2015) have found in their research that collaborative learning requires the students to solve the same question with only one answer which they should arrive at through discussion and negotiation to reach a consistent answer.

Lastly, learning about theories of writing before being asked to do the task of writing, is also one of the findings of the students' need in learning writing. Besides being able to compose sentence, text, or even essay, students also need 
to know how to be the a good writer, why they are writing, what to be considered when writing, and what to be assessed in writing.

\section{CONCLUSIONS}

The proficiency level of the students in writing is elementary. In this level, students are able to use words and grammar to make a good sentence. Brown (2004) has claimed that students in elementary level are able to produce appropriate vocabulary within a context, collocation, idioms, and correct grammatical features up to the length of sentence. Therefore, students need to develop their knowledge in all aspects and indicators of writing, whether it is a sentence or even a paragraph. In addition, students need to be provided with various learning strategies to increase their learning motivation. In relation to this, it is found that using the picture and step-by-step instruction are necessary for students in writing sentences. Furthermore, most students prefer to have tourism as the topic of their writing. This is due to the fact that Lombok is the tourist destination, all of which is presented in collaborative work.

\section{REFERENCES}

Brown, H. D. (2004). Language Assessment: Principles and Classroom Practices. New York: Longman.

Defazio, J., Jones, J., Tennant, F., \& Hook, S. A. (2010). Academic literacy: The importance and impact of writing across the curriculum: A case study. Journal of the Scholarship of Teaching and Learning, 10(2), $34-47$.

Dudley-Evans, T., \& St John, M. J. (2011). Developments in ESP: A multi-disciplinary approach. Cambridge, UK: Cambridge University Press.

Gillies, R. M., \& Ashman, A. F. (2003). An historical review of the use of groups to promote socialization and learning. London: Routledge.

Harding, K. (2007). English for Specific Purposes. Oxford: Oxford University Press.

Hutchinson, T., \& Waters, A. (1987). English for Specific Purposes: A Learning-centered Approach. Cambridge: Cambridge University Press.

Kaewpet, C. (2009). A Framework for Investigating Learner Needs: Needs Analysis Extended to Curriculum Development. Electronic Journal of Foreign Language Teaching, 6(2), 209-220.

Kayl, H. (2008). Developing an ESL Curriculum Based on Needs and Situation Analysis: A Case Study. Journal of Language and Linguistic Studies, 4(1), 30-49.

Kuo, Y. C., Chu, H. C., \& Huang, C. H. (2015). A Learning Style-based Grouping Collaborative Learning Approach to Improve EFL Students' Performance in English Courses. Journal of Educational Technology \& Society, 18(2), 284-298.

Nation, I. S. P., \& Macalister, J. (2010). Language Curriculum Design. New York: Routledge.

Petrova, I. (2008). Needs analysis as a starting point for designing a syllabus for English for specific purposes course (Master Thesis). Estonia: University of Tartu Department of English Language and Literature.
Richards, J. C. (2001). Curriculum Development in Language Teaching. Cambridge, UK: Cambridge University Press.

Tomlinson, B. (2008). English language learning materials: A critical review. London, UK: Continuum. 